\title{
Interlibrary Loan of Special Collections Materials: An Overview and Case Study
}

When the Annie Belle Weaver Special Collections, in partnership with the Interlibrary Loan department at the University of West Georgia’s Irvine Sullivan Ingram Library, embarked on loaning original materials to other libraries, we did so with a lack of consensus from the special collections world at large, about whether lending special collections materials was a good practice or not, what to lend, and to whom to lend.

The only consensus about loaning special collections materials is that there is no consensus, to rephrase the finding of the 2010 OCLC Sharing Special Collections Working Group survey. ${ }^{1}$ That survey, along with another conducted by OCLC in the same year, provided statistics on the number of institutions who were or were not interlibrary loaning special collections materials. The 2010 OCLC Sharing Special Collections Working Group survey found that " $57.4 \%$ of respondents will lend physical items from their special collections within a consortium, while another $10.3 \%$ will lend even beyond their favored group." In Taking Our Pulse: The OCLC Research Survey of Special Collections and Archives, 33 percent of respondents checked "no" to this question: "Do you permit interlibrary loan of original special collections materials?" 2 Data from both surveys align to indicate that roughly 67 percent of special collections may be lending original sources. ${ }^{3}$

Since 2010, an increasing number of librarians have called for action on expanded resource sharing of special collections materials. Christian Dupont, now Associate University Librarian for Special Collections at Boston College, particularly advocated for changes to the special collections profession in balancing issues of preserva-

1. Dennis Massie, Tiers for Fears: Sensible, Streamlined Sharing of Special Collections (Dublin, Ohio: OCLC Research, 2013), 18, available online at www.oclc.org/content/dam/research/publications/ library/2013/2013-03.pdf [accessed 27 March 2015]. The exact statement read: "In other words, the survey showed us what we suspected already: that there is currently no consensus on any aspect of sharing special collections."

2. Jackie M. Dooley and Katherine Luce, Taking Our Pulse: The OCLC Research Survey of Special Collections and Archives (Dublin, Ohio: OCLC Research, 2010), 11, available online at www.oclc.org/research/ publications/library/2010/2010-11.pdf [accessed 27 March 2015].

3. Inclusion of the possible response, "Yes, but only reproductions/copies," to which 44 percent of respondents answered affirmatively in the Taking Our Pulse survey may have diluted the accuracy of the results around the loaning of original materials. See the Taking Our Pulse survey question number 30 on page 123 and figure 1.11 for responses on page 40. 
tion versus access and trust versus risk. ${ }^{4}$ The benefits of interlibrary loan of special collections materials were also noted in the 2013 Research Library Issues, "Special Issue on Mainstreaming Special Collections," in which Lisa Carter framed the activity as "operationally integrated" within the function of academic libraries. Carter called for various library units to work together toward enhancing access to special collections materials, which, she asserted, builds trust and creates efficiencies and thus benefits patrons and the library as a whole. ${ }^{5}$

Library and archival literature historically has largely dodged the topic of loaning original special collections materials. Dennis Massie, in the 2013 OCLC report, asserted, "It remains among the most divisive issues in the field of archives and special collections, perhaps the one most likely to bring out equal parts raw emotion and well-reasoned professional opinion." ${ }^{3}$ Mary Jo Pugh, in a Society of American Archivists publication in the Archival Fundamentals Series, stated, "Loans are the exception in archives and manuscript repositories, not the rule."7 Risk is the number one answer for not engaging in interlibrary loan of special collections materials, according to Massie's OCLC report. In the special collections profession, it is noted that security and preservation of materials is a balancing act with patron access. ${ }^{8}$ There is a risk of letting special collections materials outside our institutional walls; but, in certain circumstances, like ours at the University of West Georgia, the benefits outweigh the risks. This article provides an overview of loaning materials from special collections to other libraries; documents the University of West Georgia's first year of this practice, including the factors that led to implementation, as well as the policies, procedures, and assessment measures that were put into place to ensure viability; and suggests considerations for the future.

\section{Interlibrary Loan in the Context of Resource Sharing}

Loaning original special collections materials is one of the many activities that falls under the umbrella of resource sharing. Resource sharing encompasses interlibrary loan (delivery of both original and digital content), scan-on-demand services, user-

4. Most recently, see Christian Dupont, "The Future Meets the Past: Collaborative Resource Sharing Workflows for Special Collections Materials" presentation, "The Future of Resource Sharing" conference organized by OCLC and LYRASIS, Macon, Georgia, May 17, 2013, available online at www. academia.edu/3538149/The_Future_Meets_the_Past_Collaborative_Resource_Sharing_Workflows_ for_Special_Collections_Materials [accessed 31 March 2015].

5. Lisa Carter, "Special at the Core: Aligning, Integrating, and Mainstreaming Special Collections in the Research Library," Research Library Issues 283 (2013): 3, available online at http:/ / publications.arl. org/rli283 [accessed 31 March 2015].

6. Massie, Tiers for Fears, 11.

7. Mary Jo Pugh, Providing Reference Services for Archives \& Manuscripts (Chicago: Society of American Archivists, 2005), 242.

8. See Sidney E. Berger, Rare Books and Special Collections (Chicago: Neal-Schuman, An imprint of the American Library Association, 2014), 40-42. See also the Association of College and Research Libraries, ACRL/RBMS Guidelines Regarding Security and Theft in Special Collections available online at www.ala.org/ acrl/standards/security_theft, section 6 "The Researcher" [accessed 27 March 2015]. 
initiated copy and scan activities in reading rooms, reproduction (traditional copying) services, and more. ${ }^{9}$ Some, like Wake Forest University's Z. Smith Reynolds Special Collections and the Special Collections Research Center at the University of Chicago Library, have created scan workflows directly in their interlibrary loan software to deliver digitized content directly to patrons. ${ }^{10}$ Other scanning programs include user-driven digitization in the reading room, like that of San Diego State University. ${ }^{11}$ Other institutions digitize materials based on patron requests and place the files with metadata in their content management system or digital repository to reach a broader audience. ${ }^{12}$ Digitization is an alternative method of sharing resources that alleviates institutional concerns about potential loss of the physical item or damage during transit. ${ }^{13}$ However, there are times when the loan of original materials makes more sense for patrons. Some of these scenarios include: reaching an audience that does not have Internet connectivity, reaching an audience that may not have computer fluency, and serving patrons who seek information beyond the text and are looking at the materiality of the item. It is important to clearly differentiate the lending of original materials from the provision of surrogates to patrons through various methods because the processes, policies, risks, people involved, and how well the outcome satisfies a patron's needs can vary significantly.

\section{Parameters for Loaning Special Collections Materials}

What types of materials are lent is a crucial question. In the Taking Our Pulse survey, 38 percent of respondents indicated that printed volumes are loaned and 18 percent of respondents loaned "other formats." ${ }^{14}$ With the breadth of formats contained in special collections-from microfilm reels to original letters, and from

9. See 2011 Rare Books and Manuscripts (RBMS) Preconference seminar artifacts, "Yes, We Scan! Innovative Approaches to User-initiated Digitization," available online at http://rbms.info/ conferences/2011docs/ [accessed 18 May 2015].

10. Anna Dulin and Ellen Makaravage, "Preserving and Sharing: Bridging the Gap Between ILL and Special Collections," presentation at the ILLiad International Conference, March 2012, available online at https: / / www.atlas-sys.com/ conference2012/presentations/Preserving\%20and\%20Sharing, \%20Bridging\%20the\%20Gap\%20Between\%20ILL\%20and\%20Special\%20Collections.pdf [accessed 18 May 2015]. Another example is at the University of Chicago. See Julia Gardner, "License to ILL: Partnering with InterLibrary Loan to Fulfill Special Collections Requests," seminar presentation at the RBMS Conference, June 22, 2011, available online at http://rbms.info/conferences2/preconfdocs/2011/SeminarBGardner. pdf [accessed 18 May 2015].

11. See Anne Bahde, "You're Putting What in My Reading Room?!??" seminar presentation at the RBMS Conference, June 22, 2011, available online at http:/ / rbms.info/ conferences2/preconfdocs/2011/ SeminarBBahde.pdf [accessed 19 May 2015].

12. See Jennifer Schaffner, Francine Snyder, and Shannon Supple, Scan and Deliver: Managing Userinitiated Digitization in Special Collections and Archives (Dublin, Ohio: OCLC Research, 2011), available online at www.oclc.org/research/publications/library/2011/2011-05.pdf [accessed 20 May 2015]. For another example, see Kristine J. Shrauger and Lee Dotson, "Scan by Numbers: Interlibrary Loan Lending Statistics Shape Digital Initiative," Journal of Interlibrary Loan, Document Delivery \& Electronic Reserves 20, no. 3 (2010): 135-48.

13. For discussion on this topic, see Shrauger and Dotson, "Scan by Numbers."

14. Sidney E. Berger, Rare Books and Special Collections, 40. 
medieval manuscript leaves to modern artists' books - the size, shape, weight, material components, and fragility of special collections holdings are critical factors in the decision-making process of physical and digital resource sharing. Furthermore, when considering loaning of original archival collections, there are multiple risks including theft, physical vulnerability, and loss of control over materials that could contain restricted content. The theft question is exacerbated due to lack of item counts in many archival collections (there are container counts, but that is in contrast to bound volumes, which as single items are easily countable). To reprocess collections to obtain folder-level item counts or to create item-level lists would be to return to the pre-MPLP (More Product, Less Process) era. ${ }^{15}$

Often the physical contents of an archival collection contain various formats and are housed in a variety of boxes, oversize folders, and tubes. Some collections contain oversize materials, like artworks, which are stored in oversize folders within flat file drawers or are individually wrapped in acid-free paper and tied with string. Whole archival collections can be physically awkward, even necessitating various trucking methods for transporting them to in-house patrons. Moreover, the financial investment in archival supplies by institutions is significant, and the integrity of the archival housing may be compromised during shipment. Finally, the packing and shipping costs of a near-infinite variety of housings becomes burdensome when considering a wholesale interlibrary loan of an entire collection. Selection criteria by material type or size may help to alleviate this problem; however, a short list of suitable materials may diminish the research value to the off-site patron who might otherwise benefit from an archival collection in its totality.

Content is another question, as many minimally processed collections, university archives as an example, may not have been systematically reviewed for Social Security numbers, student information protected under the Family Educational Rights and Privacy Act (FERPA), medical information protected under the Health Insurance Portability and Accountability Act (HIPAA) or privileged information. Many university archives, due to the volume of materials transferred to special collections, are reviewed for restrictions by a curator on site just before serving the materials to patrons. The high level of contact between researchers and special collections staff in the reading room allows for the chance that patrons might bring an item containing restricted content to the staff's attention. Reticence in moving forward to serve off-site patrons can also be based on potential legal and other ramifications. This may be overcautious, and perhaps interlibrary loan materials 
could be accompanied by an accompanying sensitive-materials statement; but the December 2014 incident at the University of Oregon, in which confidential electronic files were released and two staff members are no longer working in special collections, does cause one pause ${ }^{16}$ Additionally, reviewing the contents of each container is a bigger time investment than reviewing a single item for suitability. With the complex issues of archival collections, it simply becomes more difficult to make a blanket statement: "Yes, we loan original archival materials."

The realm of institutions to whom original materials will be lent is another question. The potential damage and theft risks in loaning original materials is, for some institutions, mitigated by the mandate, desire, or comfort level with sharing among consortial partners. The University of California System, as an example, lends original special collections materials within their consortia. ${ }^{17}$

\section{Increasing Access to UWG's Special Collections}

The mission of the Annie Belle Weaver Special Collections at the University of West Georgia (hereafter, "UWG") is like those of many other academic special collections: to collect, preserve, and make publicly accessible print and archival materials for the purposes of teaching, learning, and research. In 2013, Special Collections began a program to broaden public discovery of, and access to, the primary sources in its holdings. This program included implementation of Encoded Archival Description (EAD) finding aids online, accelerated digitization of high-researchvalue items (largely grant-funded work in which digitization took place off-site and content is hosted off-site at the Digital Library of Georgia), and an investigation into other resource-sharing methods, including interlibrary loan.

There were specific aspects of our library's situation that made loaning original special collections materials a potential choice: 1) our resource-sharing capacity, which at UWG was minimized by a lack of onsite robust digitization infrastructure; 2) patron demand; and 3) the nature of our print collections. Another key factor is that there was an existing culture of cooperation in Ingram Library. Special Collections and Interlibrary Loan departments worked together to develop a pilot project, make changes, and implement the program based largely on the

\footnotetext{
16. The Society of American Archivists provided a listing of select news stories on the "The University of Oregon Situation," available online at http:/ / www2.archivists.org/groups/issues-and-advocacyroundtable/the-university-of-oregon-situation [accessed 1 April 2015]. See also the Society of American Archivists, "SAA Response to Member Request re University of Oregon Records Release Incident," available online at http: / / www2.archivists.org/news/2015/ saa-response-to-member-request-re-universityof-oregon-records-release-incident [accessed 1 April 2015].

17. See University of California Libraries, RSC Committee documents, particularly the "Response to the UC Interlibrary Loan of Special Collections Materials Report" of July 2005. Information about the RSC, including documents, are available online at http:/ libraries.universityofcalifornia.edu/ rsc/rscdocuments [accessed 8 April 2015].
} 
foundation of the ACRL/RBMS Guidelines for Interlibrary and Exhibit Loan of Special Collections Material. ${ }^{18}$

In terms of resource sharing, there was a disparity in access to bound print materials between onsite patrons and off-site patrons. Onsite researchers in Special Collections could freely use books and take images of them for research purposes (the use of digital cameras is welcomed after patrons are trained in proper handling and use of book supports). In contrast, off-site patron requests for interlibrary loan, reproductions, and scans for bound materials were flatly refused: first, because of a lack of policies and procedures; and, second, because the library lacked the equipment (an overhead cradle scanner) to provide reproductions or scans of bound materials. For our institution, outright loan of bound items was easier to accomplish. There was also a disparity in access to archival materials between onsite and off-site patrons; however, we could fulfill requests for photocopies and scans for most of the materials in archival collections (with the exception of oversized, bound, or otherwise problematic materials) because the library had a flatbed copier and a flatbed scanner to do so. A portion of audio and video holdings, particularly oral history interviews, had been digitized and were available online through the Digital Library of Georgia, so access to audio and motion picture materials contained in archival collections has been more readily available.

Since 2004, the number of requests for items in Special Collections has generally risen. Requests reported in ILLiad, our request management system, were nearly exclusively for printed materials. There were only two archival lending requests recorded in ILLiad. However, the primary method of contact from borrowing institutions pertaining to archival collections' lending was by telephone call. These phone calls were not tracked, although interlibrary loan staff remember inquiries anecdotally as common, around 1-2 calls per month. All archival collection lending requests were directed to the Special Collections department, which then communicated that none of Special Collections' holdings were available for loan.

The years 2008 through 2010 saw a decrease in requests of Special Collections holdings, primarily due to the fact that Interlibrary Loan was short-staffed and went to nonlender status on occasion. A secondary factor may be that Ingram Library underwent renovation in 2010, which impacted the ability to access the physical collections; interlibrary loan requests were depressed for the library's holdings overall during this period. In the midst of the library’s renovation, a major parapsychology library, the David Wayne Hooks collection (a 1,600-volume library of books

18. Association of College and Research Libraries, ACRL/RBMS Guidelines for Interlibrary and Exhibit Loan of Special Collections Material, available online at www.ala.org/acrl/standards / special collections [accessed 1 November 2014]. 
published during the nineteenth and twentieth centuries, covering subjects such as life after death, extrasensory perception, out-of-body experiences, apparitions, and altered states of consciousness) was moved from circulating stacks to Special Collections. Previously, these books had been lent without restrictions, but the decision was made to move them due to the rarity of some of the titles and the significant loss rate due to theft. The sudden increase in special collections lending requests in 2011 is directly attributable to the move of the Hooks collection to Special Collections. Lending requests remained relatively stable from 2012 to 2014, but they are increasing due to the acquisition and subsequent cataloging of the Ingo Swann library (another major parapsychology collection on paranormal and psychic phenomenon). Projections for 2015, based on data from January to June of that year, indicate that we will exceed 120 lending requests for Special Collections materials.

FIGURE 1. Requests for loan of Special Collections materials, 2004-June 2015

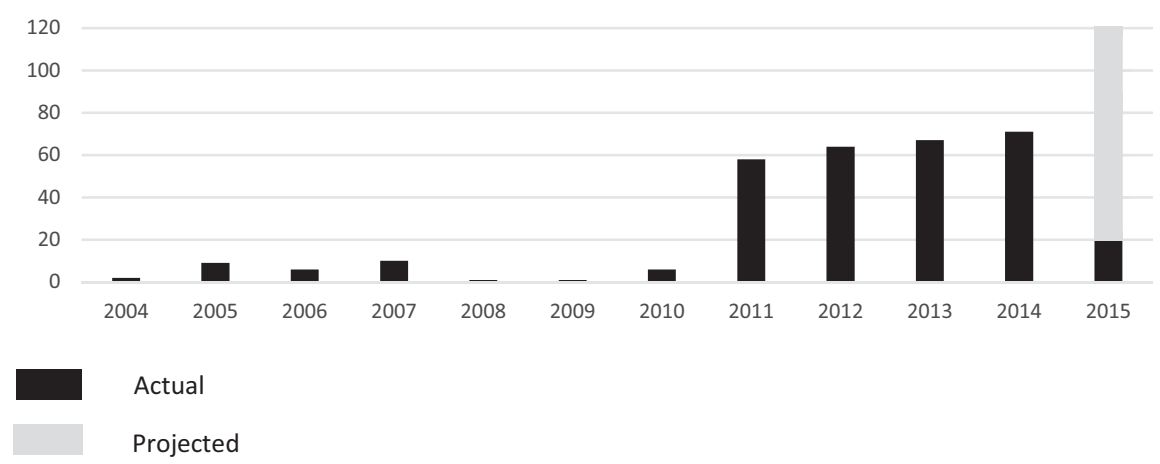

Our Interlibrary Loan department has been the beneficiary of generous interlibrary loan practices from other institutions, including items that are often difficult to obtain, generally due to age and rarity. Interlibrary Loan has received reproductions, including complete copies of pamphlets and out-of-print items, from other special collections, archives, and special libraries. Interlibrary Loan, however, had never received the loan of an original bound volume. While Interlibrary Loan attempted to facilitate as many requests as possible and absorb the cost, in the past, requesting patrons from UWG were referred to the other library when an item was unavailable for loan. If travel was not feasible, and copies were unavailable, the patron was unable to use the item. The Special Collections and Interlibrary Loan departments at UWG began to address this access barrier to facilitate and encourage research by loaning original special collections print materials.

The specific circumstances of Special Collections' print holdings, which date from the late sixteenth century to present, also drove the decision to implement loaning of original items. The loan of original archival materials was not deemed feasible 
or sustainable due to potential theft, concerns relating to the count and extent of collections, concerns about the array of container types and expense to replace, and issues of content. In the fall of 2014, a preservation assessment survey of printed materials in UWG's Special Collections, funded by a National Endowment for the Humanities grant, was completed by Etherington Conservation Services. The final preservation report noted that the majority of the printed materials were in stable condition, with approximately 16 percent of the holdings categorized as vulnerable. ${ }^{19}$ While stable, most of the bound printed holdings were a far cry from what the industry would call "very fine." In truth, many of the books would fall into the poor to good condition category in that they have been well worn and some have been rebound in library buckram, a situation that made Special Collections even more inclined to loan because, why not let the item live out its useful life in the hands of many? Furthermore, a large swath of books in Special Collections could be categorized as "medium rare" but exist on the other side of main-stacks eligibility due to their subject matter, or most importantly in the case of Special Collections, provenance. Special Collections was willing to tolerate lending to other special collections but not willing to risk potential theft from our own library main stacks.

It was also the subject strengths of the print collections, particularly in parapsychology, that made interlibrary loan a high reward situation. Many of the titles in this subject area are scarce and there has been increasing demand by onsite patrons for these titles, as well as from off-site patrons. One of the most requested areas of interlibrary loan for all of our library's holdings is in the field of psychology. Essentially, many of the books were in decent enough condition to travel, and these unique titles could potentially be very useful to scholars.

One other influential factor in being willing to consider loaning of special collections materials was that the principal investigator observed resource-sharing activities while at the University of Washington Libraries' Special Collections from 2009 to 2012, which included interlibrary loan of microfilm, scan and deliver, and Special Collections serving as a reading room for borrowed rare materials from other institutions. The process at the University of Washington Libraries was efficient and had evident benefits for users of the materials. ${ }^{20}$

In the course of considering the lending of original materials, UWG investigated the potential of a consortial partnership within the University System of Georgia,

19. Matt Johnson and ECS Conservation, Preservation Assessment Report for the Annie Belle Weaver Special Collections, Ingram Library, University of West Georgia, 2014.

20. The principal investigator wishes to thank Heidi Nance, Head of Interlibrary Loan and Document Delivery Services at the University of Washington Libraries, for a telephone interview to confirm details of UW Libraries Special Collections resource sharing. 
of which it is a part. The Manager of UWG's Interlibrary Loan department queried, via e-mail, nine universities in Georgia about their special collections lending policies and procedures to probe the possibilities for consortial lending. The universities included the seven institutions in the "research and comprehensive" tiers (one of which had two separate libraries, each with respective special collections units) and one state university that offers a graduate program in archival studies, all of which are part of the University System of Georgia. A large private university in Atlanta was also queried. Seven libraries, representing six institutions, responded to the query. Five respondents reported that their special collections departments do not lend items through interlibrary loan; instead, patrons are directed to contact special collections to arrange for an in-house use appointment or to obtain reproductions. Two respondents stated that, while they do not have written policies and procedures, they do informally lend special collections holdings on a case-bycase basis and use their ILL department to facilitate shipping. The results of this informal survey indicated that a consortial interlibrary loan arrangement for special collections materials was not yet feasible in the University System of Georgia.

\section{UWG's Pilot Project and Implementation}

In July 2014, a member of UWG's art department asked to borrow a limitededition book, held by another institution's special collections, for her research. In this instance, Special Collections served as a reading room for an item that required supervised in-library use only. This request, and subsequent successful fulfillment, coincided with the investigation of loaning of special collections materials. At that point, the Special Collections and Interlibrary Loan departments sought administrative approval from both the Library Dean and from the Head of Access Services, both of whom responded enthusiastically to the idea, and the pilot project began.

From July through October 2014, the pilot project for interlibrary loan, limited to select printed materials, was initiated with the purpose of enhancing access, supporting research, and promoting awareness of materials in the Annie Belle Special Collections. It was decided at the beginning that it was unsustainable for Special Collections to be the sole mediator for all resource sharing. Thus, this was an entirely cooperative venture between the two departments: Interlibrary Loan would handle the business end of the transactions, and Special Collections would conduct reference interviews for requesting patrons as needed, evaluate requested items for suitability, and serve patrons borrowed materials.

While the pilot was underway, the Head of Special Collections began finalizing policies and procedures in close communication with the Interlibrary Loan department. The policies and procedures were largely adapted from the ACRL/ RBMS Guidelines for Interlibrary and Exhibition Loan of Special Collections Materials, 
as the document describes very specific aspects to consider including handling, loan periods, and requirements of borrowing institutions, and more. ${ }^{21}$ Additionally, documentation from the University of California Libraries Resource Sharing Committee, dating from 2003 to a recent April 2013 procedures list, were also very helpful. ${ }^{22}$ The resulting guidelines were an eight-page document with two separate pages detailing the workflows for lending and for borrowing. ${ }^{23}$

After the final draft of the "Interlibrary Loan Policies and Procedures for Special Collections Materials" was completed in November 2014, an Interlibrary Loan staff member devised a workflow for such requests. This involved creating a custom conditional message in ILLiad, an e-mail template detailing the terms and conditions for a loan, and an e-mail template to be sent to Special Collections, all of which would be sent through ILLiad's e-mail interface (this attaches copies of all e-mails to a specific request in the database). When a borrowing request is received for an item in Special Collections, the Interlibrary Loan lending assistant responds with a conditional message on OCLC, indicating that the item is located in Special Collections. A detailed e-mail is sent to the borrowing institution's interlibrary loan contact with the details of the lending terms: the item is for special collections reading room use only, no renewals, no reproductions on a flatbed scanner or copier, and no labels. The item is to be insured for $\$ 500$ on return. If the borrowing library can meet those terms and responds "yes" through OCLC and a return e-mail, the request is forwarded via e-mail to the Head of Special Collections, who makes a determination about the item's suitability for copying or lending and details any additional lending requirements or restrictions. Suitability criteria are based on an item's condition, rarity, and value, as well as other potential factors. Special Collections completes a brief suitability form, and images are taken of the item.

If Special Collections agrees to a loan, the item is brought to the Interlibrary Loan office (materials are always passed hand-to-hand) and secured in a locked cabinet in the Interlibrary Loan office until it is sent out. Interlibrary Loan staff (not student assistants) package the item for shipment. A book band is attached that includes information on all lending conditions. When the item is returned, Interlibrary Loan keeps it in a locked cabinet until its return to, or retrieval by, Special Collections.

\footnotetext{
21. Association of College and Research Libraries, ACRL/RBMS Guidelines for Interlibrary and Exhibit Loan of Special Collections Material, available online at www.ala.org/acrl/standards/special collections [accessed 1 November 2014].

22. In particular, see University of California Libraries, Special Collections/Interlibrary Loan Pilot Project Final Report and Recommendations, 2003, available online at http: / /ibraries.universityofcalifornia.edu/ content/special-collectionsinterlibrary-loan-pilot-project-final-report-and-recommendations\#ill_guide [accessed 1 November 2014]. See also Deborah and Kerry Scott, "Interlibrary Loaning Special Collections: A Test Run for the University of California," Journal of Access Services 2, no. 2 (2004): 23-38.

23. University of West Georgia Ingram Library, "Interlibrary Loan Policies and Procedures for Special Collections Materials," available online at http:/ / libguides. westga.edu/ content.php?pid=33218 [accessed 1 March 2015].
} 
During the pilot project, 31 special-collections requests were received; and, after full implementation of the program, an additional 60 requests were received. The majority of the requests have been for items in the Hooks collection, the Ingo Swann library, and the regional West Georgiana collection.

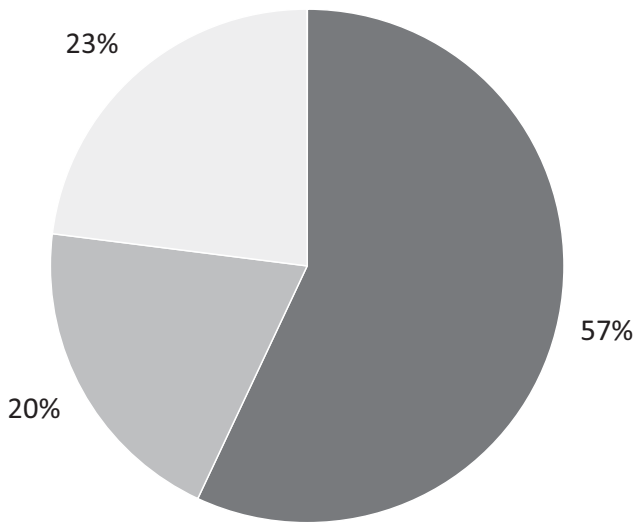

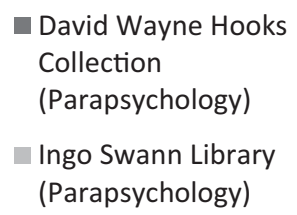

Regional History

FIGURE 2. Distribution of requests by collection, July 2014-June 2015

Many of the requests have been from public libraries for items that have additional lending libraries in the OCLC system. Since Ingram Library's Interlibrary Loan department is a free lender, our symbol is often chosen before others when a borrowing library creates a "string" of available lenders.

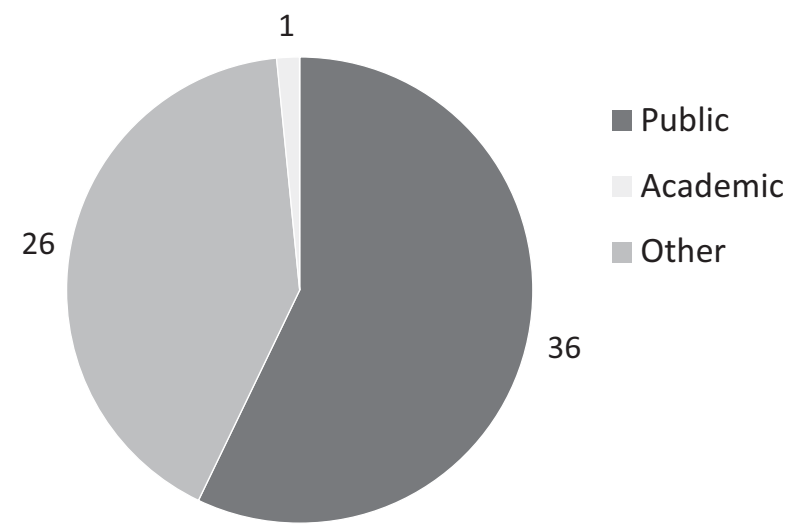

FIGURE 3. Distribution of requests by type of institution, July 2014-June 2015

In the total requests from July 2014 to June 2015, all of which were for items that met Special Collections' suitability criteria, all but three libraries refused our loan offer. The libraries cited several reasons: an inability to provide a reading room setting, the patron's refusal to accept a loan of an item that cannot leave the library, or the availability of the item elsewhere. In March of 2015, the first printed item was loaned - a book from the Hooks collection— to an academic library. The process, 
from the receipt of the borrowing request to shipping to the lending library, took 2 days.

During the course of the pilot project, statistics and information about policies and procedures were shared informally with library staff and faculty. The keenest interest in the project's progress came from the Technical Services department, which is responsible for cataloging all Special Collections materials. In particular, it was satisfying to both the Head of Special Collections and the Senior Cataloger that five interlibrary loan requests for scarce parapsychology titles held in the Ingo Swann library came in nearly as soon as the titles were cataloged. When interlibrary loan of Special Collections materials was fully implemented, it was advertised through all-faculty, all-staff, and library staff e-mail announcements. The Manager of Interlibrary Loan shared the announcement in the Georgia Library Quarterly, and the Head of Special Collections shared the news in academic faculty meetings. Our policies were also added to the OCLC Policies Directory, which facilitates information sharing regarding lending and borrowing, and provided information for the "noncirculating items/collections" section. A statement in the Special Collections/Interlibrary Loan Pilot Project Final Report and Recommendations (University of California, 2003) on patron impact particularly resonated with our experience: "The growing numbers of requests placed by users, despite little or no publicity, makes it clear that users want access to the material. ${ }^{24}$ Further publicity is planned for the annual new faculty orientation, on the library website, and in promotional literature about Interlibrary Loan and Special Collections with the hope of increasing onsite faculty and student requests for special collections materials held elsewhere.

\section{Considerations}

With the success of interlibrary loan of special collections materials in the first year, UWG remains committed to lowering boundaries around special collections and to continue enhancing patron access to the unique materials in Special Collections. The culture of Ingram Library, the collegiality and collaboration across departments, was already in place. Furthermore, our collaborative work has been nurtured by the Dean of Libraries through positive accolades, promotion of the program to deans across campus, and financial support to cover packing supplies, shipping costs, and fees associated with both lending and borrowing.

The number of fulfilled requests for both borrowing and lending is a critical set of data in assessing the program, along with the associated costs, so that the cost-

24. University of California Libraries, Special Collections/Interlibrary Loan Pilot Project Final Report and Recommendations, 2003, available online at http:/ / libraries.universityofcalifornia.edu/content/ special-collectionsinterlibrary-loan-pilot-project-final-report-and-recommendations\#ill_guide [accessed 1 November 2014], conclusion. 
benefit ratio for interlibrary loaning of special collections materials can be analyzed on an annual basis. At this point, the UWG Library has financial tolerance for the associated costs of interlibrary loaning materials and a commitment to engage in this activity.

This initiative has had many positive results for the Interlibrary Loan department as an increase in lending allows us to maintain net lender status, contributes to OCLC lending credits, and facilitates the growth of resource sharing. In fact, work on this initiative led the department to reconsider use of the microform collection, and some of those items are now available for loan.

There are two factors that were found to be outside the control of UWG: the number of incoming requests and the number of requests that are ultimately cancelled by the borrowing institution. As the number of interlibrary loan requests is far larger than the number fulfilled, UWG will be looking at the request data in terms of institutional type, reasons for cancellations by the borrowing institution, the types of materials requested (printed materials versus archival materials), and the number of denials based upon the suitability criteria. Data generated by UWG as a borrowing institution will also be examined, including: annual numbers for requests and fulfillment, institutional types of lenders, types of materials lent, and patron profile (faculty/staff or student). Lending measures are also assessed upon the return of an item including: insurance, packing, and condition of materials upon their return as compared to the condition when sent.

With 62 cancellations of requests by borrowing institutions, UWG's Interlibrary Loan observed that OCLC WorldCat and OCLC WorldShare do not provide itemlevel information that would indicate that holdings might be in special collections. The process of requesting items, particularly books, is a shot in the dark, and interlibrary loan staff do not have the time to navigate to the catalog of the holding library to look at more specific location information. Only the date or a title of a work may indicate rarity to a borrowing institution. Thus, the tide of requests from borrowing institutions is likely to continue unabated, as they are unaware at the point of the initial request that the item may have lending terms and conditions.

One procedural aspect that was corrected after the pilot project, to mitigate the above-identified problem, was the workflow timing pertaining to borrowing institutions' agreement to conditions. Special Collections had been pulling materials, reviewing them for suitability, and then—once the answer was "yes"—only then learning that the borrowing institution cancelled their request due to not having a special collections reading room. To correct this, a default e-mail is sent out to borrowing institutions just after the request is placed. The e-mail states that the 
borrowing library must meet certain conditions if UWG decides to lend. When the borrowing library affirms that they will meet the conditions, then the request is forwarded to Special Collections.

An additional note is that reviewing items for suitability for loan and completing the documentation is time consuming. Staffing to pull the items for review is critical. If requests increase over the years, it would be helpful to designate responsibility to one librarian in Special Collections to review items for lending suitability and transport them between the Interlibrary Loan and Special Collections departments.

Special collections repositories around the world are different from each other in terms of mission, audience, capacity, and the nature of their collections. Not all would have the interest, the ability, or the suitability of materials to engage in interlibrary loan of original materials. The particular circumstances at UWG-lack of digitization capacity for bound materials, patron demand for our distinctive print collections, resources to engage in interlibrary loan, and the physical stability of the majority of our printed holdings — set the stage for our interlibrary loan of original special collections materials program.

In conclusion, the implementation of interlibrary loan of printed materials has been a success in that the UWG Library has taken a major step for the benefit of off-site researchers by enhancing access to unique holdings. What roles will interlibrary loan and special collections play in the future? With the coming (not anytime soon, but still coming) ubiquity of digital access to books and other information sources, it is perhaps interlibrary loan's role to focus more on delivery of unique resources. Similarly, special collections will likely continue the trajectory of broadening public access to scarce materials. In this process we are likely to see more fluid boundaries in the work that special collections do in relation to the people we serve.

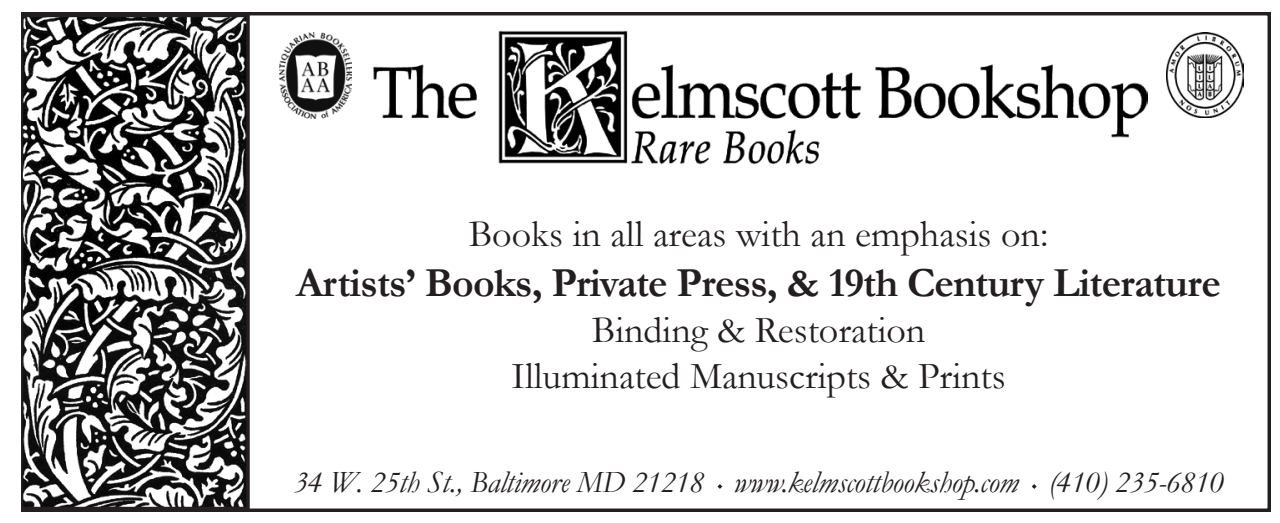

